\title{
Supplying Trade Credit, Monetary Policy and Short-term Bank Loans
}

\author{
Wenxin Wang ${ }^{1,}$ a, Wei Wang', b \\ ${ }^{1}$ School of Business, Sichuan Agricultural University, Chengdu, China, 611830; \\ ${ }^{2}$ Chengdu Communications Investment Group CO., LTD, Chengdu, China, 610041. \\ a1084053363@qq.com, byifengwww@aliyun.com
}

\begin{abstract}
This paper discusses the relationship between supply trade credit and its subdivision items with short-term bank loans. The results show that there is no significant correlation between total receivables and prepaid accounts in the current and lagged period with short-term bank loans, while the receivables were not significantly affected in the current period, the lag period was significantly negatively correlated, and the accounts receivable is a significant positive correlation in the current period, while the lag period is significantly negatively correlated. Monetary policy will affect the above-mentioned relationship.
\end{abstract}

Keywords: Trade Credit; Short-term Bank Loans; Dynamic Panel; Complementary Relationship.

\section{Introduction}

In recent years, the relationship between trade credit and bank credit has become one of the focuses of scholars (Al-Ajar and Clark, 2017). A lot of scholars start from the theory of Financing Motivation of trade credit and get an alternative relationship between trade credit and bank credit. However, there are also studies showing that there is a complementary relationship between the two, and there are also studies showing that there is no significant causal link between the uses of the two types of credit.

\section{Research Sample and Research Design}

\subsection{Sample Selection and Data Sources}

This paper takes 2007-2014 years listed companies in Shanghai and Shenzhen as research samples. The enterprise characteristic data is derived from the database of CCER and CSMAR. The level of regional management environment is derived from the 2014 report on the operating environment index of China's provincial enterprises (Wang Xiao et al.). Finally, our sample includes 11098 observations (including missing values) of 1410 sample firms in 2007-2014 years, which constitute unbalanced panel data.

\subsection{The Definition of the Main Variable}

\subsubsection{Short-Term Bank Loans and Trade Credit}

The variables involved in this paper include: The Short-term Bank Loan (Bank loan), The Enterprise Receivable (YSHJ), Bill Receivable (YSPJ), Accounts Receivable (YSZK), and Prepaid Account (YFKX).

The specific measurement methods are as follows: Bank Short-term Loan (Bank loan) $=($ end bank short-term loan / enterprise total assets), Bill Receivable (YSPJ) $=$ (final receivable bill / enterprise assets), Accounts Receivable (YSZK) = (end of term receivable / enterprise total assets), Prepaid Account $(Y S K X)=($ end of term prepaid / enterprise total assets $)$.

\subsubsection{Monetary Policy}

Referring to Zhang Dishing's (2010) method, we analyze the difference between the GDP growth rate and CPI growth rate and the M2 growth rate (DIF), the interbank interest rate (IOR) and the 7 day bond repo rate (RPR) between the banks as the original variables, and obtain a comprehensive index that can reflects the degree of tightness of monetary policy. 
The greater the value of the (GDP growth rate +CPI growth rate - M2 growth rate), the 7 - day interbank lending rate and the 7 - day debt repo rate, the tighter the monetary policy is. Therefore, the larger the comprehensive index is, the tighter monetary policy will be. We define 2011, 2012, 2013 and 2014 as the monetary policy tightening period $(\mathrm{HBZC}=1)$, and the other 4 large ones are the policy easing period $(\mathrm{HBZC}=0)$.

\subsection{Model Setting}

In view of the above problems, we draw lessons from previous chapters and past experience, and we have designed the empirical equation of this paper.

$$
\begin{aligned}
& \text { Bankloan }_{i, t}=\alpha_{0}+\sum_{j=1}^{p} \alpha_{j} \text { Bankloan }_{i, t-j}+\beta_{1} \text { TradeCredit }_{i, t}+\beta_{2} \text { TradeCredit }_{i, t-1}+\beta^{\prime} \text { Control }+\varepsilon \\
& \text { Bankloan }_{i, t}=\alpha_{0}+\sum_{j=1}^{p} \alpha_{j} \text { Bankloan }_{i, t-j}+\beta_{1} \text { TradeCredit }_{i, t}+\beta_{2} \text { TradeCredit }_{i, t-1}+\beta_{3} \text { HBZC }+ \\
& \beta_{4} \text { TradeCredit }_{i, t} * \text { HBZC }+\beta^{\prime} \text { Control }+\varepsilon
\end{aligned}
$$

Among them, Bank loan represents the short-term bank loans obtained by the enterprise ; Trade Credit is a vector containing eight variables, \{YSHJ; YSPJ; YSZK; YFKX $\}$; The enterprise provides trade credit, and their sub items respectively; HBZC is a monetary policy virtual variable; Trade Credit *HBZC represents the interaction of trade credit and its subdivision and monetary policy in the current period; Control is the other possible influence factors, including: Enterprise Scale(Size),Main Business Growth Rate (Grow), Enterprise Financial Leverage (Leverage), Capital Expenditure (KHz), Asset Tangible (Styx). A0 is a constant term, $\varepsilon$ is a random perturbation that obeys the normal distribution.

\section{Empirical Results}

As shown in table 1, model 1-2 is the impact of total receivables, and monetary policy on the shortterm bank loans of the sample banks. The result of model 1 shows that there is no significant correlation between the total receivables and the short-term bank loans of the current banks in the lag periods of the sample companies. Model 2 added monetary policy on the basis of model 1, which resulted in a significant positive correlation between monetary policy and short-term bank loans of enterprise, indicating that in the period of tight monetary policy, the proportion of short-term bank loans of Listed Companies in China is higher than that in monetary easing period. We can think that, on the one hand, in the period of tight monetary policy, the cost of financing from external financing is higher and the financing is relatively small, so enterprises will be more dependent on bank loans (Zheng Jun, 2013; Yu Kun, et al., 2014); on the other hand, in the period of tight monetary policy, the bank will reduce the amount of loan and tend to issue a short term. Contraction of loans, longterm loans, to control the size of loans (Fang Ilia et al., 2011). The interaction term of total receivables and monetary policy (YSHJ*HBZC) has no significant correlation with the current short-term bank loans.

Model 3-4 is the impact of bills receivable, and monetary policy on the short-term loans of the sample listed companies. In model 3-4, there is no significant correlation between the bill receivable and the short-term bank loans of the enterprise, while the lag periods is negatively correlated, but the model 3 is not significant, and the model 4 is significant. We can think that the more receivable bills in the previous period of the business are, the more cash will be withdrawn in the current period, so the less short-term loans will be applied to banks. Similar to the aggregated model, monetary policy is positively related to the short-term loan of the corporate bank, and the current account receivable and monetary policy interaction (YSPJ*HBZC) is also significantly positive for short-term bank loans. The more short-term bank loans are.

Model 5-6 is the influence of accounts receivable, and monetary policy on the short-term loans of the whole sample listed companies. In model 5-6, there is a significant positive correlation and a significant negative correlation between the accounts receivable in the previous period of business and the short-term loans of corporate banks. The more accounts receivable in the current period, the 
more short-term loans in current banks, and the possible reason is that the enterprise can obtain loans to the bank with the most mortgaged receivable (Sun Fancying, 2007; Yao Jin Lou and so on, 2011). The more accounts receivable in the previous period businesses, the more cash is withdrawn in the current period, so the demand for short-term loans of current banks is less. In models 6 , there is no significant correlation between the current accounts receivable and monetary policy (YSZK*HBZC) for the short-term loans of the current bank, that is, the relationship between the current accounts receivable and the short-term bank loans of the current period is not affected by monetary policy.

Model 7-8 is the impact of prepaid accounts, monetary policy and business environment on the short-term loans of the whole sample listed companies. In model 7-8, there is no significant correlation between the previous period of advance payment and the short-term loan of the current bank. In model 8 , there is no significant correlation between the current prepaid account and the monetary policy interaction item (YFKX*HBZC).

Table 1. Supply Trade Credit and its Subdivision Items with Short-term Bank Loans

\begin{tabular}{|c|c|c|c|c|c|c|c|c|}
\hline & YSHJ & $\begin{array}{l}\text { YSHJ* } \\
\text { HBZC }\end{array}$ & YSPJ & $\begin{array}{l}\text { YSPJ* } \\
\text { HBZC }\end{array}$ & YSZK & $\begin{array}{l}\text { YSZK* } \\
\text { HBZC }\end{array}$ & YFKX & $\begin{array}{l}\text { YFKX* } \\
\text { HBZC }\end{array}$ \\
\hline & (1) & $(2$ & (3) & (4) & (5) & (6) & (7) & (8) \\
\hline L. & $0.6691^{* * *}$ & $0.7924^{* * *}$ & $0.6679^{* * *}$ & $0.7872^{* * *}$ & $0.6817^{* * *}$ & $0.8037^{* * *}$ & $0.6695^{* * *}$ & $0.7917^{* * *}$ \\
\hline Bankloan & $(30.21)$ & $(25.88)$ & $(30.34)$ & $(24.96)$ & $(31.07)$ & $(26.06)$ & $(31.51)$ & $(28.15)$ \\
\hline L2. Bankloan & $\begin{array}{c}0.1011^{* * *} \\
(4.18)\end{array}$ & $\begin{array}{c}0.0819^{* *} \\
(2.44)\end{array}$ & $\begin{array}{c}0.1027^{* * *} \\
(4.27)\end{array}$ & $\begin{array}{c}0.0891^{* *} \\
(2.45)\end{array}$ & $\begin{array}{c}0.0966^{* * *} \\
(3.96)\end{array}$ & $\begin{array}{c}0.0819^{* *} \\
(2.47)\end{array}$ & $\begin{array}{c}0.1068^{* * *} \\
(4.27)\end{array}$ & $\begin{array}{c}0.0914^{* * *} \\
(2.79)\end{array}$ \\
\hline L3. Bankloan & $\begin{array}{c}0.0236 \\
(1.23)\end{array}$ & $\begin{array}{c}0.0980^{* * *} \\
(4.83)\end{array}$ & $\begin{array}{c}0.0234 \\
(1.16)\end{array}$ & $\begin{array}{c}0.1042^{* * *} \\
(5.28)\end{array}$ & $\begin{array}{c}0.0217 \\
(1.12)\end{array}$ & $\begin{array}{c}0.0930^{* * *} \\
(4.75)\end{array}$ & $\begin{array}{c}0.0210 \\
(1.04)\end{array}$ & $\begin{array}{c}0.0951^{* * *} \\
(5.15)\end{array}$ \\
\hline L.Grow & $\begin{array}{c}0.0001^{* * *} \\
(3.59)\end{array}$ & $\begin{array}{c}-0.0000 \\
(-0.84)\end{array}$ & $\begin{array}{c}0.0002^{* * *} \\
(3.56)\end{array}$ & $\begin{array}{c}-0.0000 \\
(-1.46)\end{array}$ & $\begin{array}{c}0.0001^{* * *} \\
(3.39)\end{array}$ & $\begin{array}{c}-0.0000 \\
(-0.87)\end{array}$ & $\begin{array}{c}0.0001^{* * *} \\
(4.21)\end{array}$ & $\begin{array}{c}-0.0000 \\
(-1.50)\end{array}$ \\
\hline L.Size & $\begin{array}{c}0.0024^{* *} \\
(2.44)\end{array}$ & $\begin{array}{c}0.0041^{* * *} \\
(4.91)\end{array}$ & $\begin{array}{c}0.0025^{* *} \\
(2.55)\end{array}$ & $\begin{array}{c}0.0042^{* * *} \\
(5.86)\end{array}$ & $\begin{array}{c}0.0024^{* *} \\
(2.20)\end{array}$ & $\begin{array}{c}0.0038^{* * *} \\
(4.48)\end{array}$ & $\begin{array}{c}0.0023^{* *} \\
(2.48)\end{array}$ & $\begin{array}{c}0.0043^{* * *} \\
(5.79)\end{array}$ \\
\hline L.Leverage & $\begin{array}{c}0.0834^{* * *} \\
(7.43)\end{array}$ & $\begin{array}{c}0.0082 \\
(0.90)\end{array}$ & $\begin{array}{c}0.0798^{* * *} \\
(6.64)\end{array}$ & $\begin{array}{c}0.0065 \\
(1.07)\end{array}$ & $\begin{array}{c}0.0814^{* * *} \\
(6.62)\end{array}$ & $\begin{array}{c}0.0089 \\
(1.01)\end{array}$ & $\begin{array}{c}0.0817^{* * *} \\
(7.71)\end{array}$ & $\begin{array}{l}0.0072 \\
(1.10)\end{array}$ \\
\hline L.Zbkz & $\begin{array}{c}0.0957^{* * *} \\
(11.41)\end{array}$ & $\begin{array}{c}0.0768^{* * *} \\
(6.54)\end{array}$ & $\begin{array}{c}0.0961^{* * *} \\
(12.14)\end{array}$ & $\begin{array}{c}0.0753^{* * *} \\
(6.45)\end{array}$ & $\begin{array}{c}0.0962^{* * *} \\
(11.52)\end{array}$ & $\begin{array}{c}0.0806^{* * *} \\
(6.79)\end{array}$ & $\begin{array}{c}0.0954^{* * *} \\
(12.19))\end{array}$ & $\begin{array}{c}0.0775^{* * *} \\
(6.73)\end{array}$ \\
\hline L.Zcyx & $\begin{array}{c}0.0641^{* * *} \\
(8.05)\end{array}$ & $\begin{array}{c}0.0289^{* * *} \\
(3.83)\end{array}$ & $\begin{array}{c}0.0622^{* * *} \\
(8.06)\end{array}$ & $\begin{array}{c}0.0320^{* * *} \\
(4.38)\end{array}$ & $\begin{array}{c}0.0651^{* * * *} \\
(8.14)\end{array}$ & $\begin{array}{c}0.0325^{* * *} \\
(4.34)\end{array}$ & $\begin{array}{c}0.0662^{* * * *} \\
(8.33)\end{array}$ & $\begin{array}{c}0.0351^{* * *} \\
(4.86)\end{array}$ \\
\hline $\mathrm{HBZC}$ & & $\begin{array}{c}0.0061^{*} \\
(1.65)\end{array}$ & & $\begin{array}{c}0.0093^{* * *} \\
(3.38)\end{array}$ & & $\begin{array}{c}0.0094^{* * *} \\
(3.88)\end{array}$ & & $\begin{array}{c}0.0099^{* * *} \\
(3.51)\end{array}$ \\
\hline YSHJ & $\begin{array}{c}0.0190 \\
(0.60)\end{array}$ & $\begin{array}{c}0.0233 \\
(0.81)\end{array}$ & & & & & & \\
\hline L.YSHJ & $\begin{array}{c}-0.0166 \\
(-0.53)\end{array}$ & $\begin{array}{c}-0.0435 \\
(-1.48)\end{array}$ & & & & & & \\
\hline YSPJ & & & $\begin{array}{c}0.0302 \\
(0.55)\end{array}$ & $\begin{array}{c}0.0286 \\
(0.52)\end{array}$ & & & & \\
\hline L.YSPJ & & & $\begin{array}{c}-0.0148 \\
(-0.31)\end{array}$ & $\begin{array}{c}-0.1170^{* *} \\
(-2.51)\end{array}$ & & & & \\
\hline YSZK & & & & & $\begin{array}{c}0.0501^{*} \\
(1.79)\end{array}$ & $\begin{array}{c}0.0713^{*} \\
(1.65)\end{array}$ & & \\
\hline L.YSZK & & & & & $\begin{array}{c}-0.0473^{*} \\
(-1.92)\end{array}$ & $\begin{array}{c}-0.0858^{*} \\
(-1.87)\end{array}$ & & \\
\hline YFKX & & & & & & & $\begin{array}{c}0.0256 \\
(0.43)\end{array}$ & $\begin{array}{c}0.0471 \\
(1.43)\end{array}$ \\
\hline L.YFKX & & & & & & & $\begin{array}{c}0.0092 \\
(0.24)\end{array}$ & $\begin{array}{c}0.0021 \\
(0.07)\end{array}$ \\
\hline YSHJ* & & 0.011 & YSPJ* & $0.084^{* *}$ & YSZK* & -0.021 & YFKX* & 0.014 \\
\hline HBZC & & $(0.49)$ & HBZC & $(2.17)$ & HBZC & $(-1.11)$ & HBZC & $(0.31)$ \\
\hline Constant & $\begin{array}{c}-0.076^{* * *} \\
(-3.72)\end{array}$ & $\begin{array}{c}-0.102^{* * *} \\
(-5.82)\end{array}$ & $\begin{array}{c}-0.081^{* * *} \\
(-4.07)\end{array}$ & $\begin{array}{c}-0.107^{* * *} \\
(-6.95)\end{array}$ & $\begin{array}{c}-0.076^{* * *} \\
(-3.30)\end{array}$ & $\begin{array}{c}-0.100^{* * *} \\
(-5.35)\end{array}$ & $\begin{array}{c}-0.080^{* * *} \\
(-4.21)\end{array}$ & $\begin{array}{c}-0.113^{* * *} \\
(-7.06)\end{array}$ \\
\hline Year & Control & Non control & Control & Non control & Control & Non control & Control & Non control \\
\hline Wald chi $^{2}$ & $5535.35^{* * *}$ & $3084.16^{* * *}$ & $3568.60^{* * *}$ & $4106.62^{* * *}$ & $8521.43^{* * *}$ & $2701.35^{* * *}$ & $4914.65^{* * *}$ & $3784.03^{* * *}$ \\
\hline Corr1 & 0.000 & 0.000 & 0.000 & 0.000 & 0.000 & 0.000 & 0.000 & 0.000 \\
\hline Corr2 & 0.299 & 0.125 & 0.277 & 0.141 & 0.346 & 0.134 & 0.261 & 0.158 \\
\hline Sargan & 0.000 & 0.000 & 0.000 & 0.000 & 0.000 & 0.000 & 0.000 & 0.000 \\
\hline Hansen & 0.480 & 0.000 & 0.478 & 0.017 & 0.335 & 0.002 & 0.530 & 0.007 \\
\hline $\mathrm{N}$ & 5178 & 6586 & 5178 & 6586 & 5178 & 6586 & 5178 & 6586 \\
\hline
\end{tabular}




\section{Conclusion}

To sum up, there is a difference in the impact of the trade credit (Receivables) provided by the listed companies and the subdivisions of the items receivable on the short-term bank loans of the corporate current period. In particular, both the receivable and the prepaid accounts are not significantly related to the current and the lagging ones, but the receivables are not obvious in the current period. In the first stage, there is a significant negative correlation between accounts receivable and receivables. Different monetary policies also have a significant impact on the cash holdings of enterprises. During the period of tightening monetary policy, the proportion of short-term bank loans obtained by enterprises in the current period is higher. The effect of the trade credit and its subdivision on the short-term bank loans of the enterprise in the current period is different from that of the subdivision. The role of the total receivable, receivable and prepaid accounts to the shortterm bank loans of the enterprise in the current period will not be affected by the monetary policy, but should be affected by the monetary policy. The effect of collecting bills on short-term loans of current banks will be influenced by monetary policy.

\section{References}

[1]. Xiao, Fang Gang, Li Feisul. China's sub provincial business index 2011[M]. CITIC Press, 2012.

[2]. Zhang Dishing. Monetary policy, financing constraints and corporate investment decision [D]. Doctoral Dissertation, Nankeen University, China, 2010.

[3]. Sheng Jun, Lin Hong GAO, Peng Lin. Can high quality internal control increase commercial credit financing? --based on the change of monetary policy perspective [J]. Accounting Research, Vol. 06(2013), p.62-68+96.

[4]. Yu Kun, Li Hague, Zhang Xiaorong, et al. The mystery of corporate investment efficiency: financing constraint hypothesis and monetary policy impact [J]. Economic Research Journal, Vol. 49(2014) No.05, p.106-120.

[5]. Fang Yi Lai, Wang Lining, Yang Beechen, et al. Monetary policy, ownership structure and listed company bank loans [J]. Journal of Northwest Agriculture and Forestry University (Social Science Edition), Vol.11 (2011) No.06, p.63-69+74.

[6]. Sun Fancying. A new channel for corporate financing of accounts receivable pledge loan [J]. Economic Review, Vol.10 (2007), p.25-27.

[7]. Yao Jin Lou, Ding Hogue, Wang Changing, et al. An Empirical Study on the accounts receivable pledge financing of SMEs [J]. Shanghai Finance, Vol.08 (2011), p.107-112.

[8]. Al-Ajar B, Clark E. Corporate governance and cash holdings in MENA: Evidence from internal and external governance practices [J]. Research in International Business \& Finance, Vol.39 (2017), p.1-12. 